\title{
The Phytodepuration of Wastewater for Tourism Facilities in Rural Areas: The Atlas Kasbah Ecolodge-A Pilot Site in the Argan Biosphere Reserve
}

\author{
Hassan Aboutayeb, Belkacem Kabbachi, Abdelkrim Ezaidi \\ Department of Earth Sciences, Ibn Zohr University, Agadir, Morocco \\ Email: B.kabbachi@uiz.ac.ma, HassanAboutayeb@gmail.com
}

Received 2 May 2014; revised 27 May 2014; accepted 15 June 2014

Copyright (C) 2014 by authors and Scientific Research Publishing Inc. This work is licensed under the Creative Commons Attribution International License (CC BY). http://creativecommons.org/licenses/by/4.0/

(c) (i) Open Access

\begin{abstract}
In recent years, rural tourism has developed a lot and especially in the Souss Massa Drâa region, in the South West of Morocco. The need to implement an eco-friendly sewage treatment has grown accordingly to resolve the wastewater issue. In this context, a pilot project of planted filters has been achieved in the Atlas Kasbah Ecolodge. During 3 years, the water purification performance and its compliance with the requirements of environmental management were assessed. The objective was to find an eco-friendly and affordable alternative to noncompliant ditches and sumps found in the rural areas of Morocco. The monitoring of physicochemical parameters of treated wastewater has revealed a perfect adaptation of the system to the needs of rural tourism facilities both in terms of efficiency and in terms of integration into the natural environment. Thus, such a technique could be spread in remote areas.
\end{abstract}

\section{Keywords}

Sanitation, Biofilter Treatment, Environmental Management, Rural Tourism Facility, Morocco

\section{Introduction}

The evolution of wastewater purification systems has grown rapidly because of the recent increasingly stringent environmental regulations. Small communities could not use the conventional sewage systems, so since 1997, alternative treatments have been developed with the macrophytes bed filter treatments of domestic wastewater. Several studies including Boutin and Molle were recently published stressing the relevance of this process. In 
Morocco, it remains little known but there is a huge demand for this type of sewage treatment as it represents a reliable, easy-to-use technology. It not only enables an efficient sewage sludge management but it is also well accepted by the locals because of its landscape integration.

At the Atlas Kasbah, we have opted for the separation of waters. The pre-treatment applied to grey water is used for the elimination of suspended solids and it optimizes the quality of released water. The entire system is based on gravity. The tightness is ensured by compaction and also by thin layers of non-expansive iolite-dominated clay. In addition to regular materials, a natural layer of Titanium oxide sand and another one of anthracite coal are being tested. This combination represents a unique process in this pilot project, thus constituting a new contribution to improving it.

Finally, this article is structured around the following content: first a presentation of the issue, then a view of the geographical and managerial context, a description of the used method, the analysis and discussion of the results and finally conclusion.

\section{The Operating Environment of the Souss Water Resources}

The Souss basin which houses most of the Argan biosphere is located in the south-west of Morocco, in a semiarid area. There is a major tourism development mainly because of the seaside, the argan tree (Argania spinosa) and its products and the desert with its cultures. The number of hotels has grown in the last decades. Consequently, the groundwater consumption has increased to a great extent. Water resources are scarce and even more so as there are a lot of agricultural facilities and irrigation systems. But only a reasonable and fair use of water can ensure long-term survival of the agricultural and tourism activities in the Souss region.

During recent years, an evolution in water consumption has lead to:

-An alarming drop in groundwater: more than 6.5 feet/year sometimes with a decrease in the water catchment. The study called "Drinking Water Supply for Agadir Region" has identified, since 2010, a 5\% decrease of the groundwater resources each year;

-Salted water wedges in coastal aquifers resulting in an increase in conductivity;

-A scarce rain and an increase in drought in southern Morocco because of climate change.

\section{Location of the Project (Figure 1(a), Figure 1(b))}

The Atlas Kasbah Ecolodge is located in the southern part of Tighanimine village, 5 kilometers from the city of Agadir. The guesthouse has 11 rooms and is based on sustainability. It is perfectly integrated into the landscape with its traditional architecture. This accommodation facility is built on a hill on over 7.7 miles $^{2}$ of land with an estimated built up area of $25 \%$. The remaining land is used for the organic garden and plants and for livestock (poultry, sheep...).

The Ecolodge is located in an area that is also part of the tourism region Ida Outanane (PATI) launched by the Moroccan Ministry of Tourism in 2005 to promote rural tourism in the hinterland of Agadir. From a historical perspective, it is an ancient place of caravan trade. There are several remains of these periods such as the transSaharan Trade Tower of control and the ancient Saadian Tombs (XVI century). As for archaeology, some excavations have shown that there was a human presence already in the Neolithic period (about 10,000 years BP). Relations field for the use of water in this Ecolodge (Figure 2) are summarized.

In addition, proactive measures are implemented using the following criteria: water, energy, waste, perm culture, purchasing policy, the landscape integration and the external and internal awareness. In detail [1], the measures implemented within the framework of the approach on the management of water resources are listed as Figure 3.

The analysis on the initial quality of water (Table 1) used was made at the National Office of Drinking Water (ONEP). It shows that according to Moroccan standards this is a neutral water of acceptable hardness and salinity.

\section{Materials and Method: The Unconventional Vertical Flow Filter}

Major purification mechanisms rely on the combination of multiple processes in aerobic condition, successively occurring on two floors of serial processing. Vertical flow filters are powered in surface. Effluent percolates vertically through the substrate. Physical retention of suspended solids is carried out on the surface of filters. Bio- 


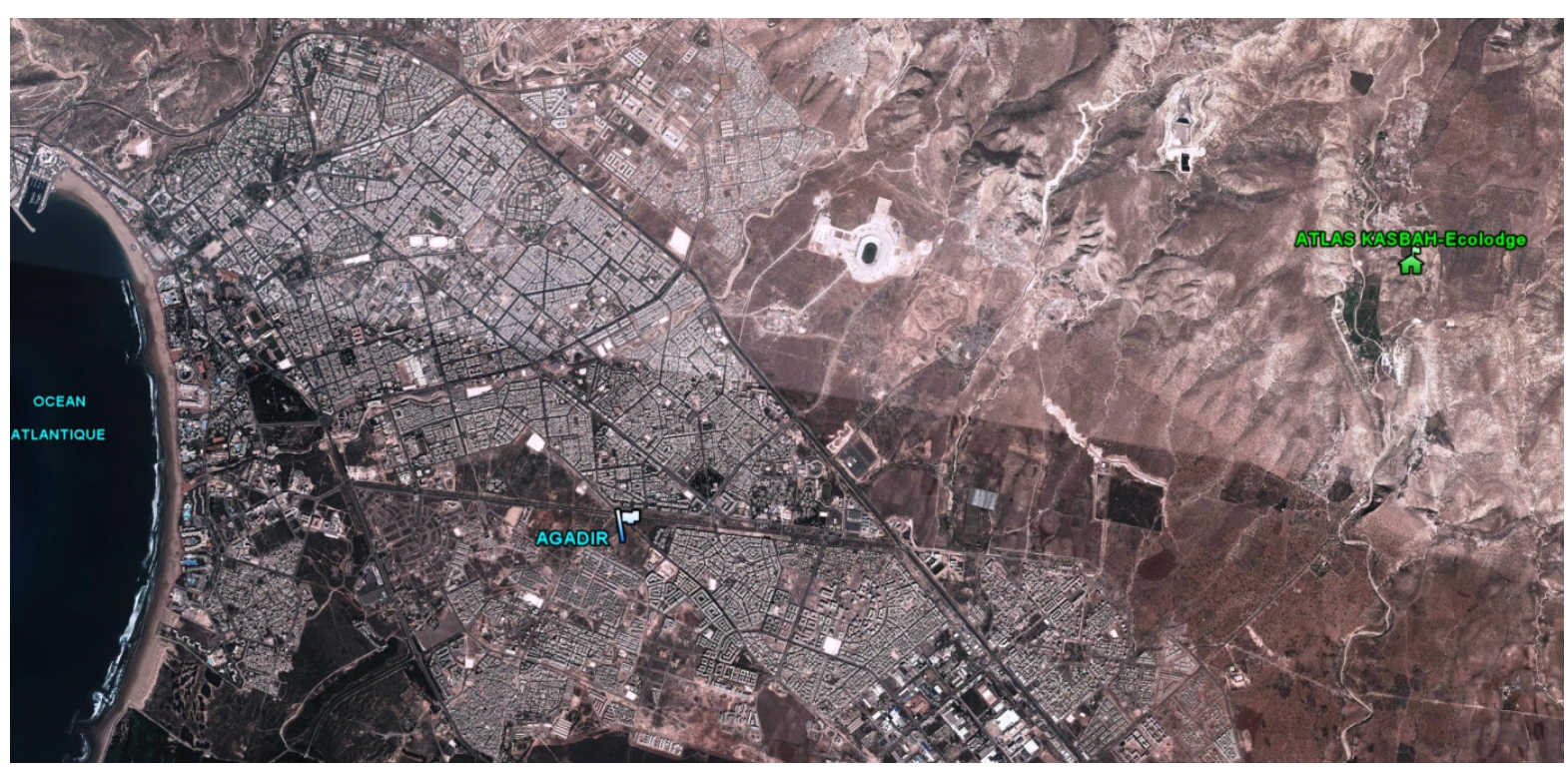

(a)

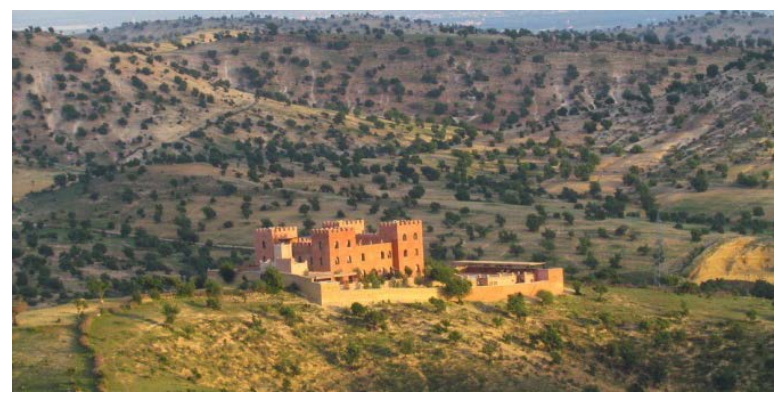

(b)

Figure 1. (a) Location of the pilot project; (b) A panoramic view of the Atlas Kasbah.

- Geological terrain with rough brownish-yellow limestone-marl inclined to 6\%;

- $\quad$ Eroded soil with a small evolution, poor in organic matter and revitalized by runoff;

- $\quad$ No drinking water supply;

- 40 m deep well with a downstream pump;

- $\quad$ Drip irrigation system on cultivated terraces (permacultures: fruits, vegetables and herbs);

- Water consumption for the accommodation $=4 \mathrm{~m}^{3} /$ day on average.

Figure 2. Characteristics and use of water in the project.

logical degradation of dissolved solids is carried out by aerobic bacterial biomass fixed on the unsaturated media. The system has the following advantages:

-Neither regular renewal filter layer nor biological sludge evacuation;

-Physical retention of suspended solids in surface filters;

-Simple technique with gravity flow;

-The area occupied is small and integrated into the overall landscape;

-Substantial savings in irrigation water especially for trees (argan, olive, orange, carob and almond);

-Preservation of soil quality and protection against contamination of the groundwater.

\section{Design and Implementation of the System of the Kasbah (Figure 4)}

The station was monitored over a period of 3 years (2012/2013/2014) with a comprehensive analysis during 
- Use of mixer taps

- Water-saving faucets

- Double speed 6 liter flush,

- No toilet paper thrown in toilet

- Showers only

- Regular inspection of valves to detect leaks

- Towels and napkins washed upon request, bed linen washed every 3 days

- Salt electrolysis swimming-pool (no chlorine)

- well water and rain water collector to irrigate the gardens;

- Use water purification system for recycling wastewater of the ecolodge for watering

Figure 3. Water control.

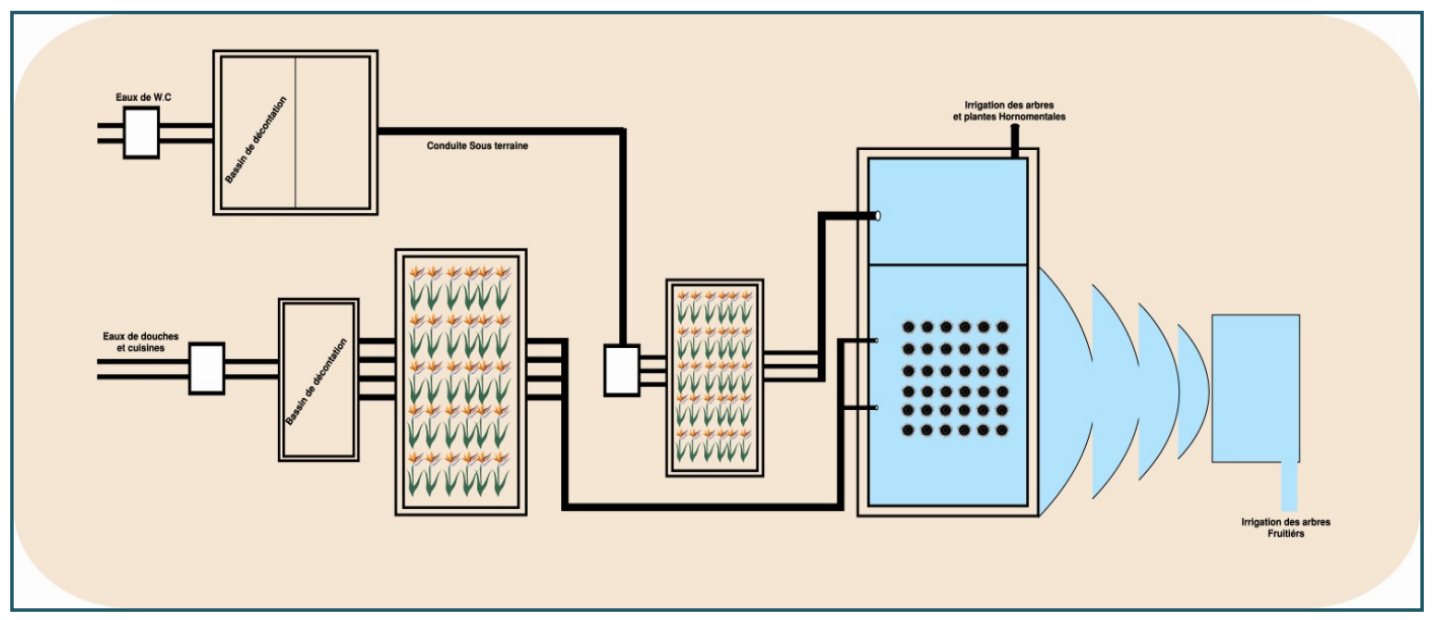

Figure 4. Diagram of the process for recycling wastewater in the Kasbah.

Table 1. Physico-chemical analysis of water from the Kasbah (ONEP, 2012).

$\begin{array}{cc}\text { Characteristics } & \text { Concentration } \\ \text { Temperature }{ }^{\circ} \mathrm{F} & \mathbf{6 7} \\ \mathrm{PH} & 7.5 \\ \text { Turbidity } \mathrm{NTU} & 46 \\ \text { Conductivity } \mu \mathrm{s} / \mathrm{cm} & \mathbf{1 7 2 0} \\ \text { Salinity } \mathrm{mg} / \mathrm{l} & \mathbf{1 2 8 0} \\ \text { Chloride }\left(\mathrm{Cl}^{-}\right) \mathrm{mg} / \mathrm{l} & \mathbf{2 8 5} \\ \text { Complete alcalimetric titration méq/l } & \mathbf{8 . 6} \\ \text { Total hardness } \mathrm{TH} \text { méq/l } & \mathbf{1 7 . 5} \\ \text { Calcium hardness mg/l } & \mathbf{1 5 6} \\ \text { Hydrogen carbonate }\left(\mathrm{HCO}-{ }_{3}^{-}\right) \mathrm{mg} / \mathrm{l} & \mathbf{5 2 4} \\ \text { Nitrate }\left(\mathrm{NO}_{3}^{-}\right) \mathrm{mg} / \mathrm{l} & \mathbf{2 0 . 5} \\ \text { Silicate }\left(\mathrm{SiO}_{3}^{-}\right) \mathrm{mg} / \mathrm{l} & \mathbf{2 5 . 5} \\ \text { Dissolved oxygen mg/l } & \mathbf{1 . 2} \\ \text { Nitrite }\left(\mathrm{NO}_{2}^{-}\right) \mathrm{mg} / \mathrm{l} & \mathbf{0} \\ \text { Ammonuim }\left(\mathrm{NH}^{4+}\right) \mathrm{mg} / \mathrm{l} & \mathbf{0} \\ \text { Fluoride }\left(\mathrm{F}^{-}\right) \mathrm{mg} / \mathrm{l} & \mathbf{0 . 5 5}\end{array}$


spring and performed on 2 samples taken spontaneously. The size of the two stories was respectively of 26 feet $\times 6.5$ feet $\times 4$ feet for wastewater and 19.6 feet $\times 6.5$ feet $\times 4$ feet for gray water. This choice was motivated by the accommodation occupancy rate which is irregular and varies between 11 and 18 guests per day for an average of $10 \mathrm{EH}$. The basins lie at an altitude of $190 \mathrm{~m}$ with a drop of $4 \mathrm{~m}$.

The station thus treats raw wastewater from a sanitary system rarely affected by pests and water running completely by gravity so without any energy supply. Upstream of the system, the water undergoes anaerobic pretreatment settling in two septic tanks with 2 compartments. According to Figure 4, the materials used in filters are made of non-carbonate aggregates to avoid the phenomena of dissolution/precipitation that could participate in obstructing porosity. A layer of natural titaniferous sand is associated with the filter as this brings very interesting levels (98\% phosphate, 98\% COD, 99\% BOD5) obtained in preliminary experiments [2].

The system consists of two vertical flow filters with cattails (Typha, Photo D) and bamboos (Phyllostachys, Photo E). Blackwater (from the restaurant and showers) and gray water (from the toilets) are treated separately throughout the process (Table 2) and eventually come out in small waterfalls in basins on a distance of 144 feet (Photo C). After this process and, in spite of the variations of hydraulic loads ( 0.03 feet to $1.6 \mathrm{feet} / \mathrm{d}$ ), the waters of the last clear and odorless basin reflect the great potential of the purifying device given the levels of discarding and objectives of reuse in agriculture (Figure 5).

\section{Performance of the Station}

The effluents are not connected to any source of metals and, the manager does not allow upstream chemicals. Tiny particles suspension settle on the surface of filters at an average height of 0.6 inches/year $\times 52$ feet $^{2} \times 0.25$

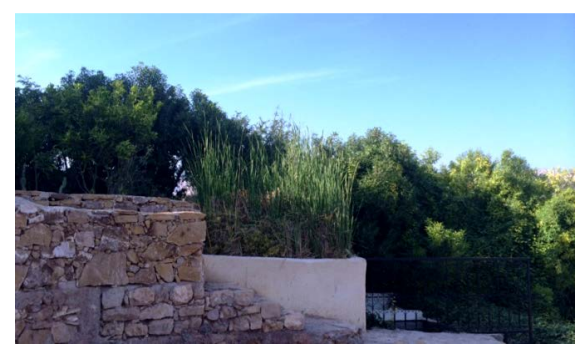

(a)

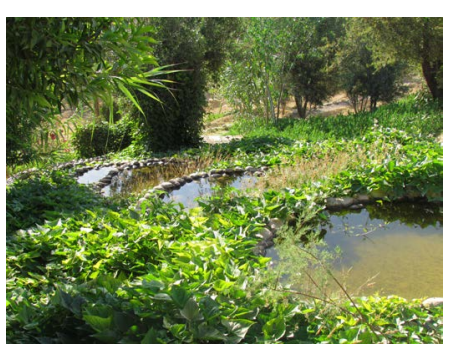

(b)

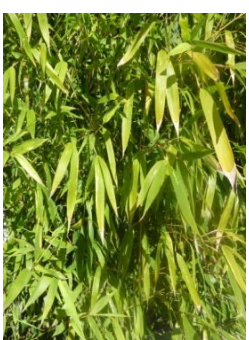

(c)

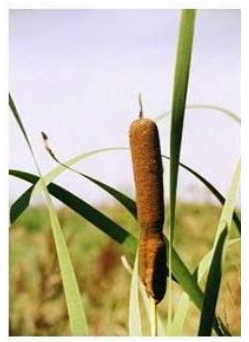

(d)

Figure 5. Picture of the switching station: (a) Biofilters; (b) Oxygenation and UV treatment; (c) \& (d) Macrophytes.

Table 2. Evolution of bio-physico-chemical parameters.

\begin{tabular}{|c|c|c|c|}
\hline Analyzed Elements & Results April-12 & Results June-13 & Results March-14 \\
\hline $\mathrm{PH}$ & 7.85 & 8.2 & 7.22 \\
\hline $\mathrm{T}^{\circ} \mathrm{C}$ & 70 & 70 & 62,6 \\
\hline Conductivity $\mu \mathrm{s} / \mathrm{cm}$ & 2600 & - & 2710 \\
\hline MIS mg/l & 32 & 8 & 20 \\
\hline MVS mg/l & 26 & - & 17 \\
\hline DBO5 mg/l & 22 & 12 & 30 \\
\hline DCO mg/l & 62 & 44 & 71 \\
\hline $\mathrm{NO}_{2}^{-} \quad \mathrm{mg} / \mathrm{l}$ & $\mathbf{0}$ & $\mathbf{0}$ & $\mathbf{0}$ \\
\hline $\mathrm{NO}_{3}^{-} \mathrm{mg} / \mathrm{l}$ & 25 & 15 & 18.5 \\
\hline PT & 4 & 13 & - \\
\hline DBO5/DCO & 0.35 & 0.27 & 0.51 \\
\hline Fecal coliform/100ml & 800 & 760 & 580 \\
\hline
\end{tabular}


$=0.40$ pounds to evacuate during three years. This mud is important to stop the infiltration rate and thus reduce the allowed $\mathrm{CH}$ [3].

Over the three years (Figure 6), the stability of the system is noticed and the performance in terms of DCO, BOD5, MIS remain largely acceptable given the best rates recorded in literature (DCO $<90 \mathrm{mg} / \mathrm{l}$ and MIS $<40$ $\mathrm{mg} / \mathrm{l})$ [4]. Given the sensitivity of the nitrification in the presence of oxygen and its competition with the carbonaceous material degradation, the stirring and oxygenation stage should be implemented during the process with the use of successive waterfalls so as to filter the output. In basins designated for that purpose, the waters are also exposed to UV rays with a view to improving their particular disinfection against $E$. coli and fecal coliforms (Table 3). The ratio between the measured values of upstream basin and downstream is close to 1.5. This system also shows encouraging results and may constitute a contribution to current trends that the filters planted chain knows [5].

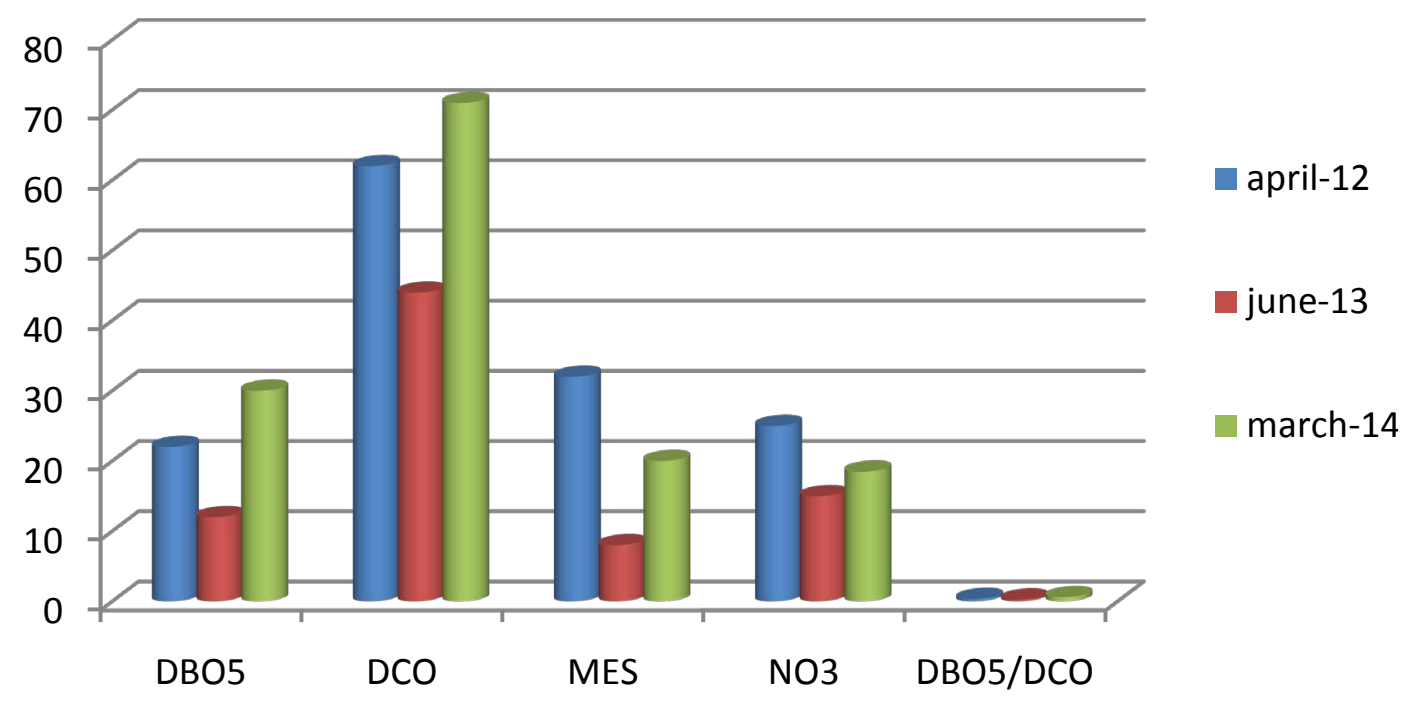

Figure 6. Comparison of the main purification indicators of the system.

Table 3. Effects of waterfalls on the treatment efficiency.

\begin{tabular}{ccc}
\hline Analyzed elements & Results & \\
\hline Sample & Downstream basin & Upstream basin \\
Sampling & Ponctual & Ponctual \\
$\mathrm{T}^{\circ} \mathrm{F}$ water $/ \mathrm{T}^{\circ} \mathrm{F}$ air & $\mathbf{6 2 . 6 / 6 3 . 5}$ & $\mathbf{6 2 . 6 / 6 3 . 5}$ \\
$\mathrm{PH}$ & $\mathbf{7 . 2 2}$ & $\mathbf{7 . 3 5}$ \\
Conductivity $\mu \mathrm{s} / \mathrm{cm}$ & $\mathbf{2 7 1 0}$ & $\mathbf{2 8 2 5}$ \\
Dissolved oxygen $\mathrm{mg} / \mathrm{O}_{2} / \mathrm{l}$ & $\mathbf{0 . 4}$ & $\mathbf{0 . 2}$ \\
$\mathrm{DBO} \mathrm{mg} \mathrm{O}_{2} / \mathrm{l}$ & $\mathbf{3 0}$ & $\mathbf{6 0}$ \\
$\mathrm{DCO} \mathrm{mg} \mathrm{O}_{2} / \mathrm{l}$ & $\mathbf{7 1}$ & $\mathbf{9 8}$ \\
$\mathrm{DBO} / \mathrm{DCO}$ & $\mathbf{0 . 4 2}$ & $\mathbf{0 . 6 1}$ \\
$\mathrm{MIS} \mathrm{mg} / \mathrm{l}$ & $\mathbf{2 0}$ & $\mathbf{2 8}$ \\
$\mathrm{MVS} \mathrm{mg} / \mathrm{l}$ & $\mathbf{1 7}$ & $\mathbf{2 1}$ \\
Nitrate $\left(\mathrm{NO} \mathrm{O}_{3}^{-}\right.$) $\mathrm{mg} / \mathrm{l}$ & $\mathbf{1 8 . 5}$ & $\mathbf{3 2}$ \\
Fecal coliform $/ 100 \mathrm{ml}$ & $\mathbf{5 8 0}$ & $\mathbf{7 3 0}$ \\
\hline
\end{tabular}




\section{Conclusion}

This pilot test has tested the efficiency of planted filters in order to use them in tourism facilities in rural Morocco. Overall, this system adapts well to local physical and socio-economic backgrounds and provides excellent purifying efficiency in spite of the variation of hydraulic loads due to the varied occupancy rate. The titaniferous sand bed seems to reinforce reduction treatments while waterfalls with UV rays represent a tertiary stage in the treatment which ensures a good final quality of the released water on all levels.

\section{References}

[1] Aboutayeb, H. (2011) Sustainable Tourism in the Biosphere Reserve of the Argan in Morocco. Editions Universitaires Européennes, 156. (in French)

[2] Agga, K., Abaaaki, R., Kabbachi, B., Ez-Zahry, M. and El Alem, N. (2013) Using the Solid Titaniferous Sand Filter as in the Process of Infiltration-Percolation Wastewater. International Conference "Water, Waste \& Environment", Abstract Book, Agadir, 48.

[3] Macrophytes and Water Treatment Group GMTE (2005) Treatment of Domestic Wastewater by Macrophytes Planted filters. Single Report, Rhône Alpe Mediterranean and Corsica Water Agency, 39. (in French)

[4] Molle, P., Lienard, A., Boutin, C., Merlin, G. and Iwema, A. (2004) State of the Art and Performance of Filters Planted Reeds in France. Engineering, Nature \& Techniques, 23-32. (in French)

[5] Molle, P. (2012) Filters Reeds Planted: Research Developments and Current Trends. Sciences Waters and Territory, 9, 24-31. (in French) 
Scientific Research Publishing (SCIRP) is one of the largest Open Access journal publishers. It is currently publishing more than 200 open access, online, peer-reviewed journals covering a wide range of academic disciplines. SCIRP serves the worldwide academic communities and contributes to the progress and application of science with its publication.

Other selected journals from SCIRP are listed as below. Submit your manuscript to us via either submit@scirp.org or Online Submission Portal.
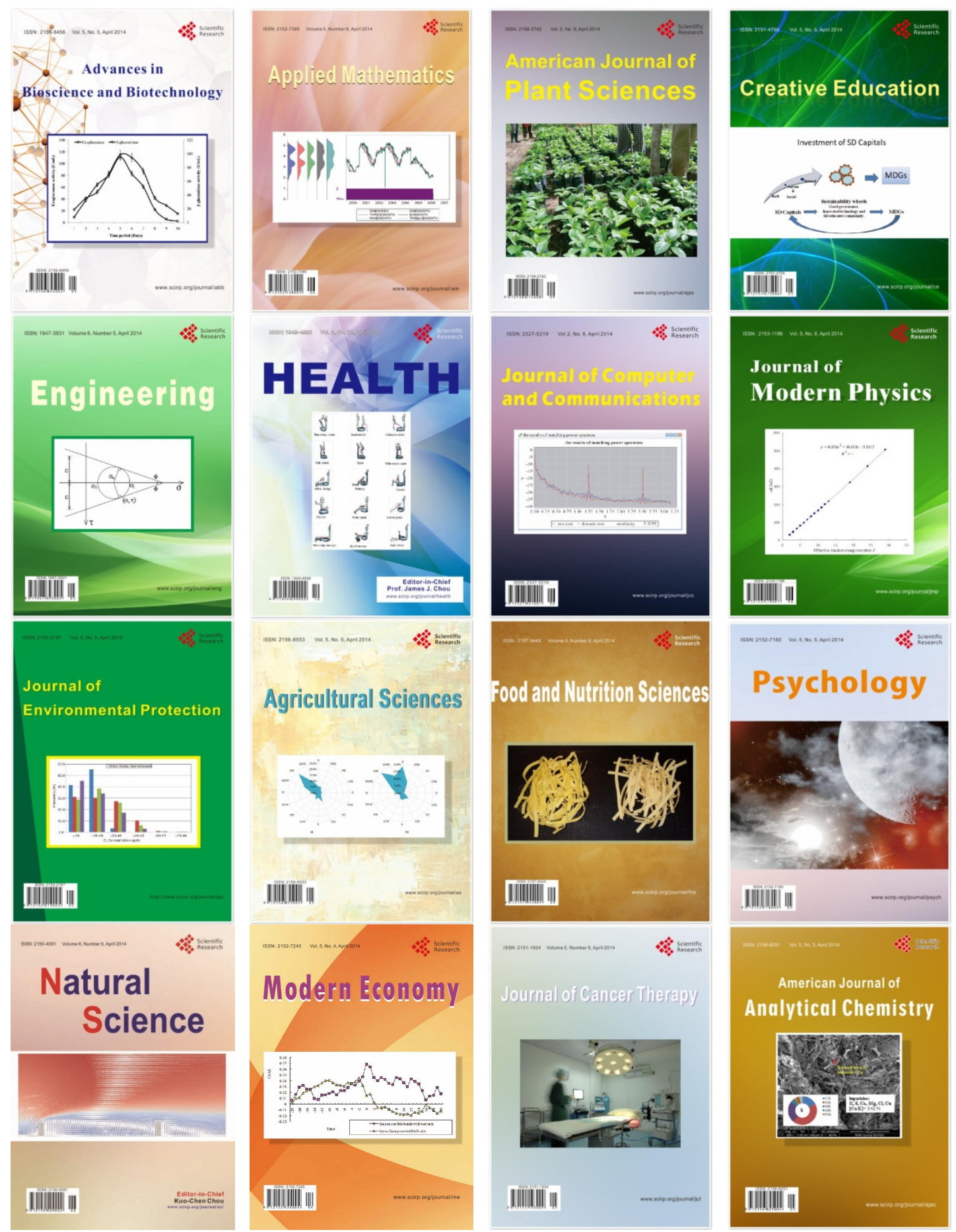